\title{
Cellular Cardiomyoplasty Using Skeletal Muscle Stem Cells
}

\author{
Elizabeth K. Lamb, Grace W. Kao, Chuanfu Li and Race L. Kao*
}

Department of Surgery, Center for Inflammation, Infectious Disease and Immunity, Quillen College of Medicine, East Tennessee State University, Johnson City, Tennessee 37614

\begin{abstract}
Skeletal muscle satellite cells (myoblasts) are the primary stem cells of skeletal muscle which contribute to growth, maintenance, and repair of the muscle. Satellite cells offer several advantages for cellular cardiomyoplasty: can be easily obtained without affecting one's function, vastly proliferated in culture, have high resistance to ischemic and hypoxic conditions, no identified risk for tumor generation, and more commitment to myogenic differentiation. Cellular cardiomyoplasty is a developing new therapy that use stem cells or progenitor cells for injured heart to improve cardiac function and mitigate heart failure. Since we first published cellular cardiomyoplasty in 1989, this procedure became one of the innovative methods to treat damaged myocardium other than heart transplantation. A significant improvement in cardiac function, metabolism, and perfusion is generally observed in experimental and clinical studies, but the improvement is mild and incomplete. Although safety, feasibility, and efficacy have been well documented for the procedure, the beneficial mechanisms remain unclear and optimization of the procedure requires further study. This paper briefly reviews the skeletal muscle stem cells used for cellular cardiomyoplasty and their clinical outcomes with possible improvements in future studies.
\end{abstract}

Keywords: Animal study, cellular cardiomyoplasty, clinical trials, skeletal muscle stem cell.

\section{INTRODUCTION}

Cardiovascular disease is the primary contributor to global mortality which accounts for more than 17.3 million deaths per year [1]. Each year, an estimated 635,000 Americans have a new heart attack for the first time with 280,000 having a recurrent coronary attack. It is also estimated that an additional150,000 Americans have silent myocardial infarction. Approximately every 34 seconds an American has a coronary event and every minute one will dies of it [2]. There are more than five million heart failure patients in the United States alone with substantial morbidity, morality, and healthcare expenditure [2]. Congestive heart failure is not a disease per se but a pathophysiologic condition which the cardiac output cannot meet the demand for normal functioning of the body. Other than replacing the failing heart (cardiac transplantation), there is no clinical therapy to cure the failing heart. Cellular cardiomyoplasty is a cell therapy using stem cells or progenitor cells to induce myogenesis and angiogenesis of an injured hart to replace, repair, maintain, and enhance ventricular function. The therapy is intended to regenerate the lost myocardium and to prevent or mitigate the progressive and irreversible loss of cardiac function and eventually heart failure.

Embryonic stem cells, adult stem cells, and induced pluripotent stem cells (iPSs) are the three major types of

*Address correspondence to this author at the Department of Surgery, Center for Inflammation, Infectious Disease and Immunity, Quillen College of Medicine, East Tennessee State University, Johnson City, Tennessee 37614; Tel: (423) 439-8803; E-mail: kao@etsu.edu stem cells that have been used for experimental and clinical studies with outcomes reviewed [3-13]. Embryonic stem cells are totipotent cells that have the capability to differentiate into any type of cell in the body. However, their application in regenerative medicine is limited due to ethical concerns, formation of teratoma, and possible rejection after utilization. Adult stem cells are undifferentiated cells residing in differentiated tissues capable of self-renewal and proliferation to produce differentiated cells. Adult stem cells can yield the specialized cell types of the tissue from which it originated and are capable of developing into cell types that are characteristic of other tissues (plasticity). Selfrenewal and plasticity of adult stem cells have been well established. This review paper will concentrate on the skeletal muscle stem cells applied for cellular cardiomyoplasty.

Ventricular muscle cells of adult mammals are terminally differentiated cells that have lost their ability to replicate by cell division. Although this view has been challenged for more than one and half century [14, 15]; clear evidence of new ventricular cardiomyocytes produced from adult mammals remains lacking [16]. Even DNA synthesis can be found in adult human heart $[17,18]$, this cannot be considered as cardiomyocyte proliferation due to DNA repair, polyploid nucleus, and multinucleated cardiac myocytes all have DNA synthesis without cytokinesis [12, $14,15,19,20]$. New heart muscle cells can be derived from extra-cardiac sources as evidenced by the male cardiac transplant recipient with female donor heart showing $\mathrm{Y}$ chromosome containing cardiomyocytes [21, 22]. However, cell fusion can also produce $\mathrm{Y}$ chromosome-positive cardiomyocytes. 
The lack of sufficient heart muscle cells to generate required pressure and output from the ventricles has been considered as the primary cause of heart failure. Myocardial infarction is normally repaired by scar formation associated with hyperplasia of nonmuscle cells and hypertrophy of cardiac myocytes. Although stem cells in the ventricular myocardium have been identified in 1996 [23] and several types of stem or progenitor cells (c-kit ${ }^{+}, \mathrm{sca}^{+}{ }^{+}$, isl- $1^{+}$, side population, and cardiosphere) have been reported in recent years [24-30], however, functionally significant myocardial regeneration has not been documented in diseased or injured heart under natural conditions. Although cardiac stem cells can give rise to cardiomyocytes, smooth muscle cells, endothelial cells, and other cell types, the cell surface markers are not specific to cardiac stem or progenitor cells [31]. In addition, the derived cardiomyocytes can be contaminants from the original tissue [21, 32]. Adult mammalian myocardium lacks adequate endogenous regenerative capability, and cellular cardiomyoplasty offers a viable approach to reconstitute damaged myocardium and prevent heart failure.

\section{SKELETAL MUSCLE STEM CELLS}

Skeletal muscle satellite cells (myoblasts) are the primary stem cells of skeletal muscle which contribute to growth, maintenance, and repair of the muscles. Satellite cells are the first stem cells used for cellular cardiomyoplasty about 25 years ago [33]. During embryonic life, myoblasts multiply and fuse to form multinuclear myotubes that mature into myofibers (muscle fibers) which are the functional units of skeletal muscle. Normal muscle growth takes place through increases in the length and diameter of existing muscle fibers with 2- to 4-fold increase in the number of muscle nuclei. Injured skeletal muscles regenerate both by repairing of surviving muscle fibers and the formation of new fibers [3438]. True muscle nuclei are postmitotic and normally cannot produce additional muscle nuclei, while injured skeletal muscle is primary regenerated from satellite cells.

Satellite cells are mononucleated myogenic precursor cells located under the basal lamina but outside the sarcolemma of skeletal muscle $[34,39,40]$. They are 25 by $5 \mu \mathrm{m}$ spindleshaped cells containing a heterochromatic nucleus and scanty cytoplasm with few organelles. The cytoplasm is dominated by large quantities of free ribosomes with some rough endoplasmic reticulum [41-43]. Satellite cell was first identified and named by Mauro in 1961 [44], since then many studies and reviews have been published $[45,46]$. Radioautographic studies reveal that dividing satellite cells are able to fuse with existing muscle fibers for providing new muscle nuclei and to fuse with themselves for forming new muscle fibers [34, 37]. In adult skeletal muscles satellite cell nuclei represent 3-6\% of all muscle nuclei with higher frequency in slow fibers as compared to fast fibers [39]. Although other skeletal muscle stem cells such as side population cells, pericytes, mesoangioblasts, and myoendothelial cells have also been identified, their contribution to growth, maintenance, or repair of muscle requires further study. For this review, we will name the skeletal muscle stem cells as satellite cells. The implantation and outcomes of cellular cardiomyoplasty using satellite cells have been reviewed $[19,33,47-50]$.

\section{EXPERIMENTAL STUDIES USING SKELETAL MUSCLE STEM CELLS}

Our group is the first one using dog satellite cells for cellular cardiomyoplasty in 1989 [51]. Since then a number of research laboratories started the similar project to confirm the safety and efficacy of satellite cells for cellular cardiomyoplasty that was summarized in our book published in May, 1997 [52] and lead to the first clinical case in 2000 [53]. Satellite cells offer several advantages for cellular cardiomyoplasty: can be easily obtained without affecting one's function, can be vastly proliferated in culture, have high resistance to ischemic and hypoxic conditions, have no identified risk for tumor generation, and have more commitment to myogenic differentiation. Formation of new muscle tissue, improvement of local perfusion, augmentation of local and global contractility, enhancement of metabolic activities, maintenance of ventricular wall thickness, decrease of scar tissue, and increase of ejection fraction and cardiac output are the observed benefits using satellite cells for cellular cardiomyoplasty [15, 19, 20, 45, 54-57].

a) Labeling of satellite cells: In order to identify the satellite cells after implantation into injured heart, it is necessary to label the cells before implantation. We have compared different labeling procedures for satellite cells in our previous publication [58]. Although satellite cells can be labeled with fluorescent microspheres $(0.49 \mu$, Polysciences Inc., Warrington, PA, USA), 4'-6-diamidino-2phenylindole (DAPI), or pulse labeled with ${ }^{3} \mathrm{H}-$ thymidine, the major limitation of these procedures is that the labeling intensity will decrease as the cell divides. The mammalian reporter vectors lacZ (pCMV $\beta$ ) from Clontech Laboratories, Inc. (Palo Alto, CA, USA), and green fluorescent protein (GFP) from Invitrogen (Carlsbad, CA, USA) can be transfected into satellite cells using Lipofectamine (Gibco BRL) (Gaithersburg, MD, USA). Transfection with Lipofectamine suffers the low-efficiency and losing labeling intensity after cell implantation.

AdenoLacZ and AdenoGFP from Quantum Biotechnologies (Montreal, Quebec, Canada) can be added directly into the culture medium, labeling the cultured satellite cells. The adenovectors offer high-efficiency labeling of satellite cells that can be detected even after 8 weeks in culture. However, to reveal $\beta$-galactosidase activity, labeled satellite cells need to be fixed, and falsepositive X-gal reaction should be carefully avoided [59]. Xgal reaction at $\mathrm{pH} 7.4$ and $37{ }^{\circ} \mathrm{C}$ for $6 \mathrm{~h}$ is recommended. AdenoGFP provides outstanding labeling efficiency with high specific and definition without interfering with the myogenic capability of labeled satellite cells.

Recently retroviral and lentiviral vectors have been developed for labeling of cells and gene transfection. 
In addition using male inbred animal donor cells and transplant into inbred female animals, the Y chromosome of donor cells can be an ideal preexisting marker for the donor cells. Fluorescence in situ hybridization (FISH) can be used to identify specific chromosomes [49]. Using inbred animals in cellular cardiomyoplasty, it is possible to use the male donor cells transplanted into female animals and identify the donor cells by the presence of $\mathrm{Y}$ chromosome. The differentiation fate of the transplanted cells can be determined by the specific cell markers by histologic or immunohistochemical procedures [60].

b) Possible beneficial mechanisms of cellular cardiomyoplasty: Although occasional cardiomyocytes developed from transplanted stem cells have been observed, the original hypothesis that stem cells restore cardiac function by massive myocardial regeneration is not supported. The possible beneficial mechanisms for cell therapy are many and a general consensus is lacking among different groups of investigators. In general the beneficial mechanisms of cellular cardiomyoplasty can be divided into myogenesis (activate contraction, improve compliance, scaffold effect, wall thickening, cell fusion, rescue damaged cells, modify matrix), angiogenesis (neovascularization, improve perfusion, enhance metabolism, minimize remolding, reverse remolding, salvage hibernating cells, rescue at-risk cells), and paracrine or endocrine effects (growth factors, angiogenic factors, cytokines, activate stem cells, mobilize stem cells, homing stem cells). The outcomes of beneficial mechanisms can be seen as: prevent infarct expansion, minimize remolding, avoid cell death, regenerate myocardium, decrease scar tissue, better blood perfusion, enhance metabolism, augment regional function and improve global function [15, 40, 57, 61-65].

\section{CLINICAL OUTCOMES USING SKELETAL MUSCLE STEM CELLS}

Skeletal muscle stem cells (satellite cells, myoblasts) were the first type of cells applied for clinical cellular cardiomyoplasty in 2000 [53]. Since then a number of smallscale uncontrolled clinical studies have been reported by different groups. Early clinical applications produced highly encouraging results and a list of clinical trials can be found from http://www.ClinicalTrials.gov. Summaries of clinical trials have been reported in several recent reviews $[19,45$, $54,55,57,66-72]$. The skeletal muscle stem cells (myoblasts, satellite cells) have been delivered into the myocardium through epicardial, endocardial or transcoronary route in the twelve short-term (one year or less) clinical trials. A significant improvement in New York Heart Association (NYHA) functional class [73, 76, 77, 79, 81, 82, 84], ejection fraction (EF) [73-78, 84], contractility [73, 74, $78,84]$, perfusion and viability of myocardium [78, 81, 84], 6-min walk [76, 82, 83], and left ventricular end systolic and diastolic volume (LV Volume) [80, 81] have been observed. Although arrhythmogenic potential and mortality have been concerned for stem cell implantation, they have not post any threat and can be easily prevented by prophylactic amiodarone. Even safety, feasibility, and efficacy have been well documented for the procedure, the beneficial mechanisms remain unclear and optimization of the procedure requires further study.

For the three long-term study (four years or longer), significant improvement in EF, NYHA functional class, and viability of myocardium were found in two of three studies that combined CABG and myoblasts transplantation [85, 86]. Percutaneous intra-myocardial skeletal muscle myoblasts injection in ischemic cardiomyopathy has no sustained positive effect during follow-up [87]. A metaanalysis of four randomized controlled trials using skeletal muscle stem cells [80-83] indicate there is no significant improvement in EF but cell therapy improved NYHA functional class and 6-min walk. No significant increase in the risk of ventricular tachycardia or acute heart failure is also confirmed [88].

Although feasibility, safety, improved survival, and ventricular functions have been observed in long-term follow-up studies, definitive long-term efficacy requires large-scale placebo-controlled double-blind randomized trials as the Myoblast Autologous Grafting in Ischemic Cardiomyopathy (MAGIC) study [80]. The MARVEL trial (NCT00526253) is a double-blind, randomized, controlled, multicenter study for 330 patients but has been terminated after 23 enrollments due to financial reasons [83]. For a small subgroup of patients in MAGIC trial that followed for an average of six years [89], the global or regional left ventricular function and arrhythmia was not changed but a significant reduction in left ventricular volume was observed that was similar to the original observations. Due to the failure and early termination of MAGIC trial, there is no active clinical trial using skeletal muscle stem cells for cellular cardiomyoplasty.

\section{FUTURE DIRECTIONS IN CELLULAR CARDIOMYOPLASTY}

Any molecular, genetic, or cellular therapies that can restore or regenerate the damaged myocardium and improve ventricular function to prevent end stage heart failure will alleviate mortality and morbidity to the patients. Unfortunately, other than heart transplant there is no clinical procedure to restore cardiac function for the patients suffering from end stage heart failure and cellular cardiomyoplasty may offer an alternative after its perfection. Although a number of different cell types have been investigated experimentally and clinically, the search for the ideal cell type or combination of cell types for cellular cardiomyoplasty is still ongoing [3-13, 61-65].

The primary beneficial mechanism after mesenchymal stem cell transplantation may be due to its paracrine effect by releasing angiogenic factors, antiapoptotic factors, and growth factors to improve perfusion, enhance metabolism, salvage damaged cells, and mobilize or activate endogenous stem cells $[3,4,9,11,90,91]$. The paracrine effect that 
regulates the cellular and molecular mechanisms of endogenous heart stem cells for myocardial regeneration and repair can offer another alternative to cellular cardiomyoplasty. Indeed, intracoronary injection of insulin like growth factor and hepatocyte growth factor [92] in a dose-dependent manner, improved cardiomyocyte survival, reduced fibrosis, and significantly increased cardiac stem/progenitor cells.

Recently, the induction of pluripotent stem cell lines from adult cells has been successfully achieved in different laboratories [93-98]. If autologous cells are used to develop the iPS, the ethical concerns and immune rejection will not limit their application [99]. To reprogram somatic cells into iPS, either retroviruses or lentiviruses are commonly used to introduce the reprogramming factors. Viral integration into the host genome increases the risk of tumorigenicity, thus viral free procedures can be used to reduce the risk of tumor formation [100, 101] however this method substantially lowers the already very low efficiency of iPS generation. Alternatively, the non-integrative sendai virus can be used to avoid viral integration into host genome [102]. Another important risk in the clinical application of human iPS is the teratoma formation by residual undifferentiated cells. Immunodepletion with antibodies against stage-specific embryonic antigen-5 and two pluripotency surface markers [103] or by lineage-specific differentiation (derivate cardiomyocyte) [104] may prevent teratoma formation.

Cardiac stem cells for cellular cardiomyoplasty have been reported with two clinical trials SCIPIO (NCT00474461) and CADUCESU (NCT00893360). The SCIPIO trial is a phase 1, randomized, open-label trial of autologous c$\mathrm{kit}^{+}$cardiac stem cells in patients with ischemic heart failure undergoing coronary artery bypass grafting (CABG) [105]. At one year follow-up [106], significant increase in LVEF, regional $\mathrm{EF}$, LV viable mass with significant decrease of infarct size and LV nonviable mass have been observed. With a maximum of one million cardiac stem cells infused into coronary artery, more 400 million cardiomyocytes have generated within the scar tissue [106]. The CADUCESU trial is a phase 1, prospective, randomized, controlled trial using cardiosphere-derived autologous stem cells at 1.5 to 3 months after successful percutaneous coronary intervention [107]. Cells (12.5 to 25 millions) were infused into the infarct-related coronary artery using angioplasty catheter. At one year follow-up [108], significant increase in viable heart mass, regional contractility, systolic wall thickening and significant reduction in scar mass have been found. No significant safety concerns and no improvement in LVEF, NYHA functional class, 6-min walk, or quality of life have been observed. The use of cardiac stem cells for cellular caridomyoplasty has been reviewed recently [109, 110].

The method of cell delivery and enhance retention, timing and dosing of cells, survival and engraftment of cells, the adjunctive treatment or combined therapies will not be optimized till a better understanding of the beneficial mechanisms on cellular cardiomyoplasty. The stem cells have been delivered to the heart through coronary system (intracoronary artery, retrograde coronary venin, intravevein, or intraventricular administration) or by direct injection into myocardium (epicardial, transendocardial, or transcoronary injection) [111]. The retention and engraftment rates of the cells are very low due to biological and mechanical losses $[9,33]$. Within hours to one day about $10 \%$ of the injected cell can be found by intramyocardial route and only 2 to $3 \%$ remain in the heart after coronary delivery [112-114]. With progress decreases by time, around one month about $1 \%$ or less of the transplanted cells can be found in heart $[114,115]$. Using microspheres with approximating size of stem cells to rule out cell death and degradation; similar results have been found as stem cells and cell leakage, wash out, and mechanical squeeze may be the main causes of cell losses[116-118]. Theoretically even a few stem cells survived at the transplant site, they should be able to proliferate to vast quantity in a reasonably short time, but the robust proliferation of transplanted stem cells has not been observed.

Improving cellular retention, survival, mobilization, homing, and differentiation are different areas that can improve the outcomes of cellular cardiomyoplaty. The retention and engraftment rates of the cells are very low due to biological and mechanical losses [9, 33, 119, 120]. Microencapsulation [121], nanobiotechnology [122], tissue engineering [123], and magnetic targeting [124] all significantly increased cell retention and engraftment of implanted cells. Preconditioning of cells, pharmacologic agent, and genetic modification of stem cells are additional procedures to improve survival, mobilization, homing, and differentiation of stem cells for cellular cardiomyoplasty [33, 125-128].

Before resolving the problems of cell retention and survival, studying the dose and time of cell administration may be meaningless due to the extremely low retention and engraftment rate. Most studies indicate that high dose of cells $\left(>10^{8}\right)$ are more beneficial than the lower doses. Although early cell therapy ( $\leq 7$ days) after myocardial infarction seems more effective than delayed treatment [129132], the delayed treatment also provides significant improvement in left ventricular function. More importantly, timing of treatment from animal studies cannot directly translate to clinical study. The changes in pathologic state is faster in smaller animals than large animals and humans after myocardial infarction. Therefore, relative pathologic state rather than actual date should be considered. To overcome the lack of trans-differentiation for skeletal muscle and bone marrow stem cells, treating the cultured cells with retinoic acid, dimethyl sulfoxide, 5-azacytidine or other compound [133] can induce them differently into cardiomyocytes. Alternatively induction of cardiac fibroblasts into cardiomyocyte-like cells [134-139] can be another way of myocardial regeneration. Cardiomyogenic pretreatment significantly increased the formation of cardiac myocytes after their transplantation into the injured heart [140] and different stem cells may require different treatment [141, 142].

Cellular cardiomyoplasty has been moved rapidly from animal experiment to clinical trials with highly encouraging results. Unfortunately the beneficial mechanisms lack general consensus that limit the optimization of the procedure. Although cell therapy has proved to be 
significantly beneficial to acute myocardial infarction, chronic ischemic cardiomyopathy, and heart failure patients; the beneficial outcomes are moderate. After a better understanding regarding the mechanisms of cellular cardiomyoplasty, the ideal cell type or combination of cell types, the optimal dose and time of treatment, and the beneficial adjunct therapies can be devised.

\section{CONFLICT OF INTEREST}

The authors confirm that this article content has no conflict of interest.

\section{ACKNOWLEDGEMENTS}

This work was supported by NIH grants HL072138, GM093878 and AHA grants 09GRNT2020111, 02555009B to RLK; NIH grants HL071837 and GM083016 to CL.

\section{REFERENCES}

[1] www.who.int/entity/cardiovascular_diseases/en/ Assessed 09/15/2014.

[2] Go AS, Mozaffarian D, Roger VL, et al. Heart disease and stroke statistics--2014 update: a report from the American Heart Association. Circulation 2014; 129(3): e28-292.

[3] Kao RL, Ed. Cellular Cardiomyoplasty: Methods and protocols. New York: Springer 2013.

[4] Telukuntla KS, Suncion VY, Schulman IH, Hare JM. The advancing field of cell-based therapy: insights and lessons from clinical trials. J Am Heart Assoc 2013; 2(5): e000338.

[5] Finan A, Dong F, Penn MS. Regenerative strategies for preserving and restoring cardiac function. Front Biosci (Elite Ed) 2013; 5: 232-48.

[6] Bernal A, Gálvez BG. The potential of stem cells in the treatment of cardiovascular diseases. Stem Cell Rev 2013; 9(6): 814-32.

[7] Gho JM, Kummeling GJ, Koudstaal S, et al. Cell therapy, a novel remedy for dilated cardiomyopathy? A systematic review. J Card Fail 2013; 19(7): 494-502.

[8] Donndorf P, Strauer BE, Haverich A, Steinhoff G. Stem cell therapy for the treatment of acute myocardial infarction and chronic ischemic heart disease. Curr Pharm Biotechnol 2013; 14(1): 12-9.

[9] Sanganalmath SK, Bolli R. Cell therapy for heart failure: a comprehensive overview of experimental and clinical studies, current challenges, and future directions. Circ Res 2013; 113(6): 810-34.

[10] Pfister O, Della Verde G, Liao R, Kuster GM. Regenerative therapy for cardiovascular disease. Transl Res 2014; 163(4): 30720.

[11] Marquis-Gravel G, Stevens LM, Mansour S, Avram R, Noiseux N. Stem cell therapy for the treatment of nonischemic cardiomyopathy: a systematic review of the literature and meta-analysis of randomized controlled trials. Can J Cardiol 2014; pii: S0828282X(14): 00184-6.

[12] Rota M, Leri A, Anversa P. Human heart failure: is cell therapy a valid option? Biochem Pharmacol 2014; 88(2): 129-38.

[13] Fox IJ, Daley GQ, Goldman SA, et al. Stem cell therapy. Use of differentiated pluripotent stem cells as replacement therapy for treating disease. Science 2014; 345(6199): 1247391-1 10.

[14] Carvalho AB, de Carvalho AC. Heart regeneration: past, present and future. World J Cardiol 2010; 2(5): 107-11.

[15] Laflamme MA, Murry CE. Heart regeneration. Nature 2011; 473(7347): 326-35.

[16] Ang KL, Shenje LT, Reuter S, et al. Limitations of conventional approaches to identify myocyte nuclei in histologic sections of the heart. Am J Physiol Cell Physiol 2010; 298: C1603-9.

[17] Soonpaa MH, Field LJ. Assessment of cardiomyocyte DNA synthesis in normal and injured adult mouse hearts. Am J Physiol 1997; 272: H220-6.
[18] Bergmann O, Bhardwaj RD, Bernard S, et al. Evidence for cardiomyocyte renewal in humans. Science 2009; 324: 98-102.

[19] Kao RL, Browder W, Li C. Cellular cardiomyoplasty: what have we learned? Asian Cardiovasc Thorac Ann 2009; 17: 89-101.

[20] Steinhauser ML, Lee RT. Regeneration of the heart. EMBO Mol Med 2011; 3: 701-12.

[21] Laflamme MA, Myerson D, Saffitz JE, Murry CE. Evidence for cardiomyocyte repopulation by extracardiac progenitors in transplanted human hearts. Circ Res 2002; 90: 634-40.

[22] Müller P, Pfeiffer P, Koglin J, et al. Cardiomyocytes of noncardiac origin in myocardial biopsies of human transplanted hearts. Circulation 2002; 106: 31-5.

[23] Warejcka DJ, Harvey R, Taylor BJ, et al. A population of cells isolated from rat heart capable of differentiating into several mesodermal phenotypes. J Surg Res 1996; 62: 233-42.

[24] Hierlihy AM, Seale P, Lobe CG, et al. The post-natal heart contains a myocardial stem cell population. FEBS Lett 2002; 530: 239-43.

[25] Beltrami AP, Barlucchi L, Torella D, et al. Adult cardiac stem cells are multipotent and support myocardial regeneration. Cell 2003; 114: 763-76.

[26] Laugwitz KL, Moretti A, Lam J, et al. Postnatal isl1 ${ }^{+}$cardioblasts enter fully differentiated cardiomyocyte lineages. Nature 2005; 433: $647-53$.

[27] Oyama $\mathrm{T}$, Nagai $\mathrm{T}$, Wada $\mathrm{H}$, et al. Cardiac side population cells have a potential to migrate and differentiate into cardiomyocytes in vitro and in vivo. J Cell Biol 2007; 176: 329-41.

[28] Bearzi C, Rota M, Hosoda T, et al. Human cardiac stem cells. Proc Natl Acad Sci USA 2007; 104: 14068-73.

[29] Tang YL, Shen L, Qian K, Phillips MI. A novel two-step procedure to expand cardiac Sca-1+ cells clonally. Biochem Biophys Res Commun 2007; 359: 877-83

[30] Smith RR, Barile L, Cho HC, et al. Regenerative potential of cardiospherederived cells expanded from percutaneous endomyocardial biopsy specimens. Circulation 2007; 115: 896-908.

[31] Anversa P, Annarosa L. Innate regeneration in the aging heart: Healing from within. Mayo Clin Proc 2013; 88(8): 871-83.

[32] Andersen DC, Andersen P, Schneider M, et al. Murine "cardiospheres" are not a source of stem cells with cardiomyogenic potential. Stem Cells 2009; 27: 1571-81.

[33] Lamb EK, Kao GW, Kao RL. Cellular cardiomyoplasty: its past, present, and future. Methods Mol Biol 2013; 1036: 1-17.

[34] Mauro A. Muscle regeneration. New York: Raven Press 1978.

[35] Brack AS, Rando TA. Tissue-specific stem cells: lessons from the skeletal muscle satellite cell. Cell Stem Cell 2012; 10: 504-14.

[36] Carlson BM, Faulkner JA. The generation of skeletal muscle fibers following injury: a review. Med Sci Sports Exerc 1983; 15: 187-98.

[37] Snow MH. An autoradiographic study of satellite cells differentiation into regenerating myotubes following transplantation of muscle in young rat. Cell Tissue Res 1978; 186: 535-40.

[38] Wang YX, Rudnicki MA. Satellite cells, the engines of muscle repair. Nat Rev Mol Cell Biol 2011; 13: 127-33.

[39] Pallafacchina G, Blaauw B, Schiaffino S. Role of satellite cells in muscle growth and maintenance of muscle mass. Nutr Metab Cardiovasc Dis 2013; 23 (Suppl 1): S1: 2-8.

[40] Kao RL, Chiu RCJ. Satellite cell implantation. In: Kao RL, Chiu RCJ. Eds. Cellular cardiomyoplasty: myocardial repair with cell implantation. New York: Chapman \& Hall 1997; pp. 129-62.

[41] Campion DR. The muscle satellite cell: a review. Int Rev Cytol 1984; 87: 225-51.

[42] Zhang M, McLennan IS. Use of antibodies to identify satellite cells with a light microscope. Muscle Nerve 1994; 17: 987-94.

[43] Kao RL. Autologous satellite cell for myocardial regeneration. Ebiomed: J Regen Med 2001; 2: 1-8.

[44] Mauro A. Satellite cells of skeletal muscle fibers. J Biophys Biochem Cytol 1961; 9: 493-5.

[45] Usas A, Mačiulaitis J, Mačiulaitis R, et al. Skeletal muscle-derived stem cells: implications for cell-mediated therapies. Medicina (Kaunas) 2011; 47: 469-79.

[46] Aziz A, Sebastian S, Dilworth FJ. The origin and fate of muscle satellite cells. Stem Cell Rev 2012; 8: 609-22.

[47] Huu AL, Prakash S, Shum-Tim D. Cellular cardiomyoplasty: current state of the field. Regen Med 2012; 7: 571-82. 
[48] Hassan N, Tchao J, Tobita K. Concise review: skeletal muscle stem cells and cardiac lineage: potential for heart repair. Stem Cells Transl Med 2014; 3(2): 183-93.

[49] Kao GW, Lamb EK, Kao RL. Skeletal muscle stem cells. methods Mol Biol 2013; 1036: 19-32.

[50] Motohashi N, Asakura Y, Asakura A. Isolation, culture, and transplantation of muscle satellite cells. J Vis Exp 2014; 86: 1-15.

[51] Kao RL, Rizzo C, Magovern GJ. Satellite cells for myocardial regeneration. Physiologist 1989; 32: 220.

[52] Kao RL, Chiu RCJ. Eds. Cellular cardiomyoplasty: myocardial repair with cell implantation. New York: Chapman \& Hall 1997.

[53] Menasché P, Hagège AA, Scorsin M, et al. Myoblast transplantation for heart failure. Lancet 2001; 357: 279-80.

[54] Menasché P. Stem cell therapy for chronic heart failure: lessons from a 15-year experience. C R Biol 2011; 334: 489-96.

[55] Menasche P. Cardiac cell therapy: lessons from clinical trials. J Mol Cell Cardiol 2011; 50: 258-65.

[56] Al-Kindi A, Ge Y, Shum-Tim D. Cellular cardiomyoplasty: evidence of cellular therapy, mechanisms and controversies. In: Prakash S, Shum-Tim D. Eds. Stem cell bioengineering and tissue engineering microenvironment. Hackensack: World Scientific Publishing Co 2011; pp. 385-440.

[57] Kolanowski TJ, Rozwadowska N, Malcher A, et al. In vitro and in vivo characteristics of connexin 43-modified human skeletal myoblasts as candidates for prospective stem cell therapy for the failing heart. Int J Cardiol. 2014; 173(1): 55-64.

[58] Zhao R, Kao RL. Comparison of labeling procedures for myogenic cells. Cardiac Vasc Regen 2000; 1: 85-91.

[59] Al-Khaldi A, Lachapelle K, Galipeau J. Endogenous $\beta$ galactosidase enzyme activities in normal tissue and ischemic myocardium. Cardiac Vasc Regen 2000; 1: 283-90.

[60] Grajales L, García J, Geenen DL. Induction of cardiac myogenic lineage development differs between mesenchymal and satellite cells and is accelerated by bone morphogenetic protein-4. J Mol Cell Cardiol 2012; 53: 382-91.

[61] Kao RL, Ganote E, Pennington DG, Borwder IW. Myocardial regeneration, tissue engineering and therapy. In: Prakash S. Ed. Artificial cells, cell engineering and therapy: Cambridge, Woodhead Publishing Ltd. 2007; pp. 349-65.

[62] Cheng K, Li TS, Malliaras K, et al. Magnetic targeting enhances engraftment and functional benefit of iron-labeled cardiospherederived cells in myocardial infarction. Circ Res 2010; 106:1570-81.

[63] Pfister O, Della Verde G, Liao R, Kuster GM. Regenerative therapy for cardiovascular disease. Transl Res 2014; 163(4): 30720.

[64] Young PP, Schäfer R. Cell-based therapies for cardiac disease: a cellular therapist's perspective. Transfusion 2014 Aug 22. [Epub ahead of print]

[65] Rota M, Leri A, Anversa P. Human heart failure: is cell therapy a valid option? Biochem Pharmacol 2014; 88(2): 129-38.

[66] Wu KH, Mo XM, Han ZC, Zhou B. (2011) Stem cell engraftment and survival in the ischemic heart. Ann Thorac Surg 2011; 92: 1917-25.

[67] Hoover-Plow J, Gong Y. Challenges for heart disease stem cell therapy. Vasc Health Risk Manag 2012; 8: 99-113.

[68] Choudry FA, Mathur A. Stem cell therapy in cardiology. Regen Med 2011; 6(Suppl 6): 17-23.

[69] Malliaras K., Marbán E. Cardiac cell therapy: where we've been, where we are, and where we should be headed. Br Med Bull 2011; 98: 161-85.

[70] Abdelli LS, Merino H, Rocher CM, Singla DK. Cell therapy in the heart. Can J Physiol Pharmacol 2012; 90:307-15.

[71] Duran JM, Taghavi S, George JC. The need for standardized protocols for future clinical trials of cell therapy. Transl Res 2012; 160(6): 399-410.

[72] Durdu S, Deniz GC, Dogan A, et al. Stem cell mediated cardiovascular repair. Can J Physiol Pharmacol 2012; 90:337-51.

[73] Menasché P, Hagège AA, Vilquin JT, et al. Autologous skeletal myoblast transplantation for severe postinfarction left ventricular dysfunction. J Am Coll Cardiol 2003; 41(7): 1078-83.

[74] Smits PC, van Geuns RJ, Poldermans D, et al. Catheter-based intramyocardial injection of autologous skeletal myoblasts as a primary treatment of ischemic heart failure: clinical experience with six-month follow-up. J Am Coll Cardiol 2003; 42(12): 2063 9.

[75] Siminiak T, Kalawski R, Fiszer D, et al. Autologous skeletal myoblast transplantation for the treatment of postinfarction myocardial injury: phase I clinical study with 12 months of followup. Am Heart J 2004; 148(3): 531-7.

[76] Ince H, Petzsch M, Rehders TC, et al. Transcatheter transplantation of autologous skeletal myoblasts in postinfarction patients with severe left ventricular dysfunction. J Endovasc Ther 2004; 11(6) 695-704.

[77] Siminiak T, Fiszer D, Jerzykowska O, et al. Percutaneous transcoronary-venous transplantation of autologous skeletal myoblast in the treatment of post-infarction myocardial contractility impairment: the POZNAN trial. Eur Heart J 2005; 26(12): 1188-95.

[78] Gavira JJ, Herreros J, Perez A, et al. Autologous skeletal myoblast transplantation in patients with nonacute myocardial infarction: 1year follow-up. J Thorac Cardiovasc Surg 2006; 131(4): 799-804.

[79] Biagini E, Valgimigli M, Smits PC, et al. Stress and tissue Doppler echocardiographic evidence of effectiveness of myoblast transplantation in patients with ischaemic heart failure. Eur J Heart Fail 2006; 8(6): 641-8.

[80] Menasché P, Alfieri O, Janssens S, et al. The myoblast autologous grafting in ischemic cardiomyopathy (MAGIC) trial: first randomized placebo-controlled study of myoblast transplantation. Circulation 2008; 117(9): 1189-200.

[81] Dib N, Dinsmore J, Lababidi Z, et al. One-year follow-up of feasibility and safety of the first U.S., randomized, controlled study using 3-dimensional guided catheter-based delivery of autologous skeletal myoblasts for ischemic cardiomyopathy (CAuSMIC study). JACC Cardiovasc Interv 2009; 2(1): 9-16.

[82] Duckers HJ, Houtgraaf J, Hehrlein C, et al. Final results of a phase IIa, randomised, open-label trial to evaluate the percutaneous intramyocardial transplantation of autologous skeletal myoblasts in congestive heart failure patients: the SEISMIC trial. EuroIntervention 2011; 6(7): 805-12.

[83] Povsic TJ, O'Connor CM, Henry T, et al. A double-blind, randomized, controlled, multicenter study to assess the safety and cardiovascular effects of skeletal myoblast implantation by catheter delivery in patients with chronic heart failure after myocardial infarction. Am Heart J 2011; 162(4): 654-662.

[84] Kao RL, Ha T, Li C, et al. Stem cell therapy for myocardial regeneration: the Chinese experience. In: Prakash S, Shum-Tim D, Eds. Stem cell bioengineering and tissue engineering microenviroment. Singapore: World Scientific 2011; pp. 457-80.

[85] Dib N, Michler RE, Pagani FD, et al. Safety and feasibility of autologous myoblast transplantation in patients with ischemic cardiomyopathy: four-year follow-up. Circulation 2005; 112(12): 1748-55.

[86] Hagège AA, Marolleau JP, Vilquin JT, et al. Skeletal myoblast transplantation in ischemic heart failure: long-term follow-up of the first phase I cohort of patients. Circulation 2006; 114 (Suppl 1): I108-13.

[87] Veltman CE, Soliman OI, Geleijnse ML, et al. Four-year follow-up of treatment with intramyocardial skeletal myoblasts injection in patients with ischaemic cardiomyopathy. Eur Heart J 2008; 29(11): 1386-96.

[88] Cheng K, Wu F, Cao F. Intramyocardial autologous cell engraftment in patients with ischaemic heart failure: a metaanalysis of randomised controlled trials. Heart Lung Circ 2013; 22(11): 887-94.

[89] Brickwedel J, Gulbins H, Reichenspurner H. Long-term follow-up after autologous skeletal myoblast transplantation in ischaemic heart disease. Interact Cardiovasc Thorac Surg 2014; 18(1): 61-6.

[90] Suncion VY, Schulman IH, Hare JM. Concise review: the role of clinical trials in deciphering mechanisms of action of cardiac cellbased therapy. Stem Cells Transl Med 2012; 1(1): 29-35.

[91] Grimaldi V, Mancini FP, Casamassimi A, et al. Potential benefits of cell therapy in coronary heart disease. J Cardiol 2013; 62(5): 267-76.

[92] Ellison GM, Torella D, Dellegrottaglie S, et al. Endogenous cardiac stem cell activation by insulin-like growth factor1/hepatocyte growth factor intracoronary injection fosters survival and regeneration of the infarcted pig heart. J Am Coll Cardiol 2011; 58(9): 977-86. 
[93] Takahashi K, Yamanaka S. Induction of pluripotent stem cells from mouse embryonic and adult fibroblast cultures by defined factors. Cell 2006; 126: 663-76.

[94] Takahashi K, Tanabe K, Ohnuki M, et al. Induction of pluripotent stem cells from adult human fibroblasts by defined factors. Cell 2007; 131: 861-72.

[95] Robinton DA, Daley GQ. The promise of induced pluripotent stem cells in research and therapy. Nature 2012; 481: 295-305.

[96] Yamanaka S. Induced pluripotent stem cells: past, present, and future. Cell Stem Cell 2012; 10: 678-84.

[97] Greenow K, Clarke AR. Controlling the stem cell compartment and regeneration in vivo: the role of pluripotency pathways. Physiol Rev 2012; 92: 75-99.

[98] Iglesias-García O, Pelacho B, Prósper F. Induced pluripotent stem cells as a new strategy for cardiac regeneration and disease modeling. J Mol Cell Cardiol 2013; 62: 43-50.

[99] Oh Y, Wei H, Ma D, et al. Clinical applications of patient-specific induced pluripotent stem cells in cardiovascular medicine. Heart 2012; 98: 443-49.

[100] Okita K, Nakagawa M, Hyenjong H, et al. Generation of mouse induced pluripotent stem cells without viral vectors. Science 2008; 322: 949-53.

[101] Burridge PW, Matsa E, Shukla P, et al. Chemically defined generation of human cardiomyocytes. Nat Methods 2014; 11(8): 855-60.

[102] Churko JM, Burridge PW, Wu JC. Generation of human iPSCs from human peripheral blood mononuclear cells using nonintegrative Sendai virus in chemically defined conditions. Methods Mol Biol 2013; 1036: 81-8.

[103] Tang C, Lee AS, Volkmer JP, et al. An antibody against SSEA-5 glycan on human pluripotent stem cells enables removal of teratoma-forming cells. Nat Biotechnol 2011; 29: 829-34

[104] Liu Z, Tang Y, Lü S, The tumourigenicity of iPS cells and their differentiated derivates. J Cell Mol Med 2013; 17(6): 782-91.

[105] Bolli R, Chugh AR, D'Amario D, et al. Cardiac stem cells in patients with ischaemic cardiomyopathy (SCIPIO): initial results of a randomised phase 1 trial. Lancet 2011; 378(9806): 1847-57.

[106] Chugh AR, Beache GM, Loughran JH, et al. Administration of cardiac stem cells in patients with ischemic cardiomyopathy: the SCIPIO trial: surgical aspects and interim analysis of myocardial function and viability by magnetic resonance. Circulation 2012; 126(11 Suppl 1): S54-64.

[107] Makkar RR, Smith RR, Cheng K, et al. Intracoronary cardiospherederived cells for heart regeneration after myocardial infarction (CADUCEUS): a prospective, randomised phase 1 trial. Lancet 2012; 379(9819): 895-904.

[108] Malliaras K, Makkar RR, Smith RR, et al. Intracoronary cardiosphere-derived cells after myocardial infarction: evidence of therapeutic regeneration in the final 1-year results of the CADUCEUS trial (CArdiosphere-Derived aUtologous stem CElls to reverse ventricUlar dySfunction). J Am Coll Cardiol 2014; 63(2): 110-22.

[109] Koudstaal S, Jansen Of Lorkeers SJ, Gaetani R, et al. Concise review: heart regeneration and the role of cardiac stem cells. Stem Cells Transl Med 2013; 2(6): 434-43.

[110] Wang WE, Chen X, Houser SR, Zeng C. Potential of cardiac stem/progenitor cells and induced pluripotent stem cells for cardiac repair in ischaemic heart disease. Clin Sci (Lond). 2013; 125(7): 319-27.

[111] Sheng CC, Zhou L, Hao J. Current stem cell delivery methods for myocardial repair. Biomed Res Int 2013; 2013: 547902.

[112] Hou D, Youssef EA, Brinton TJ, et al. Radiolabeled cell distribution after intramyocardial, intracoronary, and interstitial retrograde coronary venous delivery: implications for current clinical trials. Circulation 2005; 112(9 Suppl): I150-6.

[113] Bonios M, Terrovitis J, Chang CY, et al. Myocardial substrate and route of administration determine acute cardiac retention and lung bio-distribution of cardiosphere-derived cells. J Nucl Cardiol 2011; 18(3): 443-50.

[114] Hong KU, Li QH, Guo Y, et al. A highly sensitive and accurate method to quantify absolute numbers of c-kit+ cardiac stem cells following transplantation in mice. Basic Res Cardiol 2013; 108(3): 346.
[115] Zeng L, Hu Q, Wang $\mathrm{X}$, et al. Bioenergetic and functional consequences of bone marrow-derived multipotent progenitor cell transplantation in hearts with postinfarction left ventricular remodeling. Circulation 2007; 115(14): 1866-75.

[116] Teng CJ, Luo J, Chiu RC, Shum-Tim D. Massive mechanical loss of microspheres with direct intramyocardial injection in the beating heart: implications for cellular cardiomyoplasty. J Thorac Cardiovasc Surg 2006; 132: 628-32.

[117] Hudson W, Collins MC, deFreitas D, et al. Beating and arrested intramyocardial injections are associated with significant mechanical loss: implications for cardiac cell transplantation. J Surg Res 2007; 142(2): 263-7.

[118] Anderl JN, Robey TE, Stayton PS, Murry CE. Retention and biodistribution of microspheres injected into ischemic myocardium. J Biomed Mater Res A 2009; 88(3): 704-10.

[119] Al Kindi A, Ge Y, Shum-Tim D, Chiu RC. Cellular cardiomyoplasty: routes of cell delivery and retention. Front Biosci 2008; 13: 2421-34.

[120] Wu KH, Mo XM, Han ZC, Zhou B. Stem cell engraftment and survival in the ischemic heart. Ann Thorac Surg 2011; 92: 1917-25.

[121] Huu AL, Paul A, Prakash S, Shum-Tim D. Route of delivery, cell retention, and efficiency of polymeric microcapsules in cellular cardiomyoplasty. Methods Mol Biol 2013; 1036: 121-35.

[122] Paul A, Shum-Tim D, Prakash S. Angiogenic nanodelivery systems for myocardial therapy. Methods Mol Biol 2013; 1036: 137-49.

[123] Chachques JC, Pradas MM, Bayes-Genis A, Semino C. Ceating the bioartificial myocardium for cardiac repair: challenges and clinical targets. Expert Rev Cardiovasc Ther 2013; 11(12): 1701-11.

[124] Cheng K, Li TS, Malliaras K, et al. Magnetic targeting enhances engraftment and functional benefit of iron-labeled cardiospherederived cells in myocardial infarction. Circ Res 2010; 106:1570-81.

[125] Lu HH, Li YF, Sheng ZQ, Wang Y. Preconditioning of stem cells for the treatment of myocardial infarction. Chin Med J (Engl) 2012; 125: 378-84.

[126] Tang YL, Zhu W, Cheng M, et al. Hypoxic preconditioning enhances the benefit of cardiac progenitor cell therapy for treatment of myocardial infarction by inducing CXCR4 expression. Circ Res 2009; 104: 1209-16.

[127] Niagara MI, Haider HKh, Jiang S, Ashraf M. Pharmacologically preconditioned skeletal myoblasts are resistant to oxidative stress and promote angiomyogenesis via release of paracrine factors in the infarcted heart. Circ Res 2007; 100(4): 545-55.

[128] Cai C, Teng L, Vu D, et al. The heme oxygenase 1 inducer (CoPP) protects human cardiac stem cells against apoptosis through activation of the extracellular signal-regulated kinase (ERK)/NRF2 signaling pathway and cytokine release. J Biol Chem 2012; 287(40): 33720-32.

[129] Wen Y, Meng L, Xie J, Ouyang J. (2011) Direct autologous bone marrow-derived stem cell transplantation for ischemic heart disease: a meta-analysis. Expert Opin Biol Ther 2011; 11:559-67.

[130] Wen Y, Meng L, Ding Y, Ouyang J. Autologous transplantation of blood-derived stem/progenitor cells for ischaemic heart disease. Int J Clin Pract 2011; 65: 858-65.

[131] Zhao Q, Ye X. Additive value of adult bone-marrow-derived cell transplantation to conventional revascularization in chronic ischemic heart disease: a systemic review and meta-analysis. Expert Opin Biol Ther 2011; 11: 1569-79.

[132] Donndorf P, Kundt G, Kaminski A, et al. Intramyocardial bone marrow stem cell transplantation during coronary artery bypass surgery: a meta-analysis. J Thorac Cardiovasc Surg 2011; 142: 911-20.

[133] Haider HKh., Ashraf M. Bone marrow stem cell transplantation for cardiac repair. Am J Physiol Heart Circ Physiol 2005; 288: H255767.

[134] Kao RL, Laffan JJ, Chin TK, et al. Myogenic cardiac fibroblasts for myocardial infarction. In: Kipshidze NN and Serruys PW, Eds. Handbook of Cardiovascular Cell Transplantation. London, England: Martin Dunitz 2004; pp. 107-21.

[135] Ieda M, Fu JD, Delgado-Olguin P, et al. Direct reprogramming of fibroblasts into functional cardiomyocytes by defined factors. Cell 2010; 142(3): 375-86.

[136] Jayawardena TM, Egemnazarov B, Finch EA, et al. MicroRNAmediated in vitro and in vivo direct reprogramming of cardiac fibroblasts to cardiomyocytes. Circ Res 2012; 110(11): 1465-73. 
[137] Wada R, Muraoka N, Inagawa $\mathrm{K}$, et al. Induction of human cardiomyocyte-like cells from fibroblasts by defined factors. Proc Natl Acad Sci U S A. 2013; 110(31): 12667-72.

[138] Yi BA, Mummery CL, Chien KR. Direct cardiomyocyte reprogramming: a new direction for cardiovascular regenerative medicine. Cold Spring Harb Perspect Med 2013; 3(9): a014050.

[139] Budniatzky I, Gepstein L. Concise review: reprogramming strategies for cardiovascular regenerative medicine: from induced pluripotent stem cells to direct reprogramming. Stem Cells Transl Med 2014; 3(4): 448-57.
[140] Bittira B, Kuang JQ, Al-Khaldi A, Shum-Tim D, Chiu RC. In vitro preprogramming of marrow stromal cells for myocardial regeneration. Ann Thorac Surg 2002; 74: 1154-59.

[141] Grajales L, García J, Geenen DL. Induction of cardiac myogenic lineage development differs between mesenchymal and satellite cells and is accelerated by bone morphogenetic protein-4. $\mathrm{J}$ Mol Cell Cardiol 2012; 53(3): 382-91.

[142] Verma V, Purnamawati K, Manasi, Shim W. Steering signal transduction pathway towards cardiac lineage from human pluripotent stem cells: a review. Cell Signal 2013; 25(5): 1096-107.

Received: September 22, 2014

(C) Lamb et al.; Licensee Bentham Open.

This is an open access article licensed under the terms of the Creative Commons Attribution Non-Commercial License (http://creativecommons.org/licenses/bync/3.0/), which permits unrestricted, non-commercial use, distribution and reproduction in any medium, provided the work is properly cited. 